\title{
Synthesis and Antibacterial Activity of New Spiro[thiadiazoline-(pyrazolo[3,4-d]pyrimidine)] Derivatives
}

\author{
Mohammed El Fal, ${ }^{1}$ Youssef Ramli, ${ }^{2}$ Abdelfettah Zerzouf, ${ }^{3}$ \\ Ahmed Talbaoui, ${ }^{4}$ Youssef Bakri, ${ }^{4}$ and El Mokhtar Essassi ${ }^{1}$ \\ ${ }^{1}$ Laboratoire de Chimie Organique Hétérocyclique URAC 21, Faculté des Sciences, Université Mohammed V, Rabat, Morocco \\ ${ }^{2}$ Medicinal Chemistry Laboratory, Faculty of Medicine and Pharmacy, Mohammed V University, 10170 Rabat, Morocco \\ ${ }^{3}$ Laboratoire de Physico-Chimie des Matériaux Inorganiques et Organiques (LPCMIO), ENS, Rabat, Morocco \\ ${ }^{4}$ Laboratoire de Biochimie et Immunologie, Faculté des Sciences, Université Mohammed V, Rabat, Morocco
}

Correspondence should be addressed to Youssef Ramli; yramli76@yahoo.fr

Received 24 February 2015; Revised 16 April 2015; Accepted 20 April 2015

Academic Editor: Marco Radi

Copyright ( 2015 Mohammed El Fal et al. This is an open access article distributed under the Creative Commons Attribution License, which permits unrestricted use, distribution, and reproduction in any medium, provided the original work is properly cited.

New heterocyclic compounds spiroderivatives of allopurinol of biological interest were prepared from allopurinol via thionation and 1,3-dipolar cycloaddition and were produced in high to excellent yields. These compounds were characterized on the basis of spectral and spectroscopic data $\left({ }^{1} \mathrm{H}\right.$ NMR, ${ }^{13} \mathrm{C}$, IR, and MS). The antibacterial activity of the synthesized products was studied using bacterial strains: Staphylococcus aureus, Enterococcus faecalis, Escherichia coli, and Pseudomonas aeruginosa. Compounds having an ethyl group showed the best activity with MIC value of $31.25 \mu \mathrm{g} / \mathrm{mL}$ against Staphylococcus aureus and Streptococcus fasciens.

\section{Introduction}

Heterocycles are widely distributed in nature and play a key role in the metabolism of all living cells. Among the many heterocyclic compounds containing nitrogen, the pyrazolopyrimidine ring is very interesting and versatile scaffold for the synthesis of potential drugs or molecular tools (Figure 1). Among their many applications, pyrazolo[3,4-d]pyrimidines (Figure 2) were used as inhibitor kinases $[1,2]$ antiviral agents $[3,4]$, adenosine antagonists [5-7], glutamate modulators [8], antituberculosis agents [3], and as antibiotics inhibit bacterial growth $[9,10]$.

In light of the great importance of spirocyclic systems containing one carbon atom common to two rings [11-13], in recent years efforts have been made in developing methodologies for the synthesis of these compounds especially by cycloaddition reactions [14-22].

1,3-Dipolar cycloaddition is a subject of intense research during the last decade due to its great synthetic value.
The cycloaddition is a method of synthesis of five membered heterocycles, which are difficult to prepare by other means.

Generally, reactions of 1,3-dipoles with true heterocyclic thiones having the thione form $\mathbf{A}$ proceed via 1,3-dipolar cycloaddition to the $\mathrm{C}=\mathrm{S}$ double bond to form the spirocycloadducts, namely, spirothiadiazoles. The reaction of heterocyclic thiones $\mathbf{A}$ with nitrilimines, generated in situ by base-catalyzed dehydrohalogenation of hydrazonoyl halides, has been described for synthesis of various derivatives of spiro[heterocycle-n, $2^{\prime}$-3H-1,3,4-thiadiazole] B (Figure 3).

In continuation of our work on the synthesis of the excess of allopurinol [23-28], compounds 2 and $\mathbf{2 a - b}$ have been synthesized by using reported methods [29-31]. Herein we report simple efficient synthesis of spiro thiadiazoline(pyrazolo[3,4-d]pyrimidine) derivatives $4 \mathbf{a}-\mathbf{b}$ by 1,3-dipolar cycloaddition of diphenyl hydrazonoyl chloride 3 with an equimolecular amount of pyrazolo[3,4-d]pyrimidin-4 $(5 \mathrm{H})$ thione derivatives $\mathbf{2} \mathbf{a}-\mathbf{b}$. All the synthesized compounds were evaluated for their antibacterial activity. 


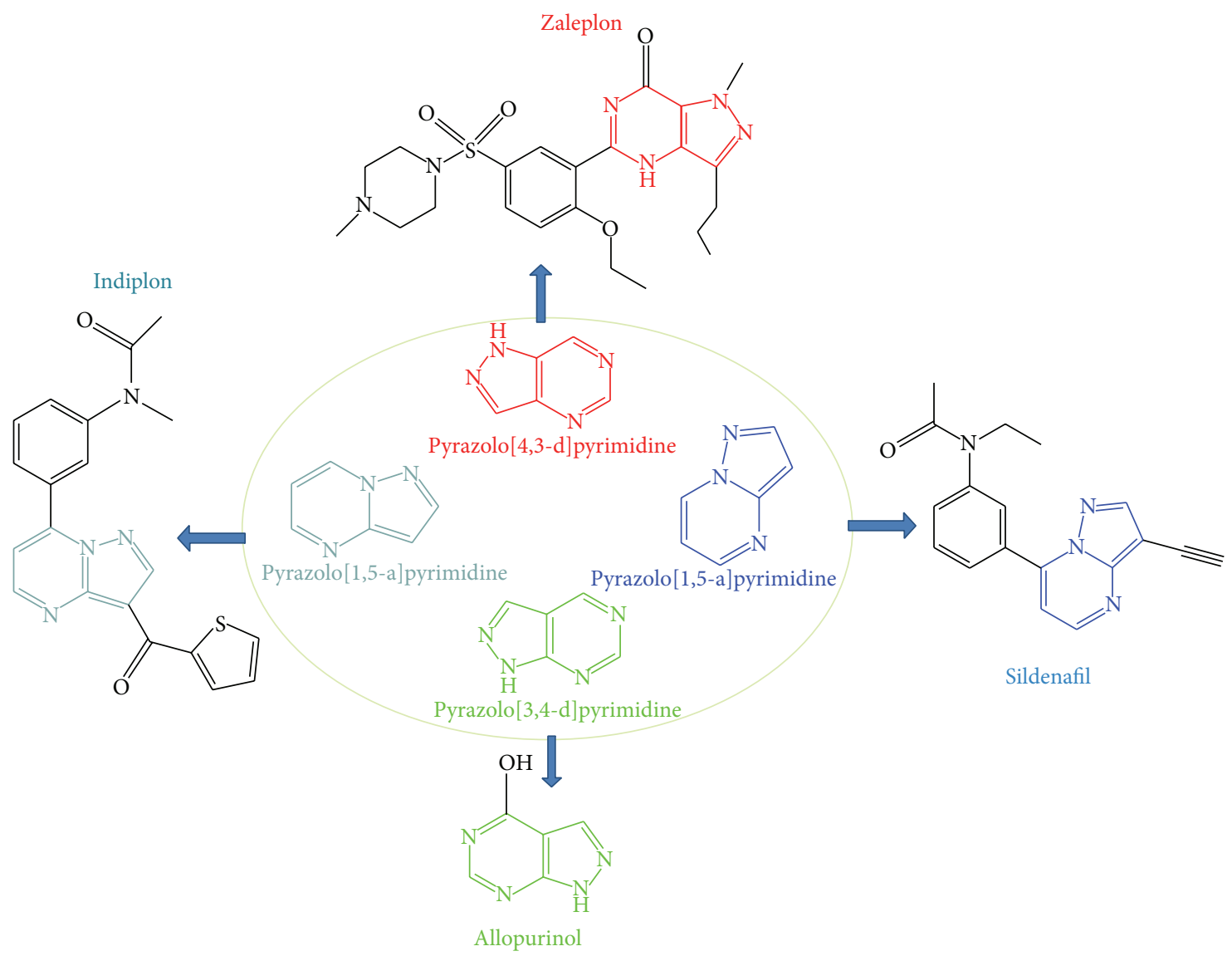

Figure 1: Pyrazolopyrimidine containing drugs.

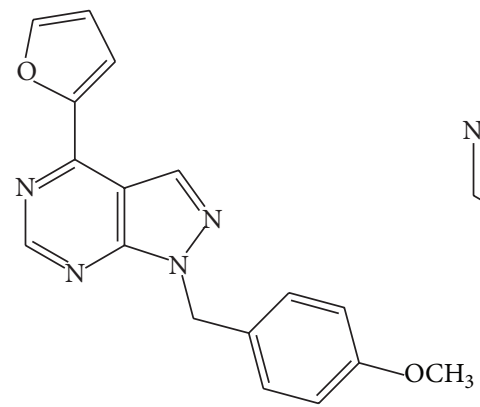<smiles>[R17]Nc1ncnc2c1cnn2[X]c1ccccc1</smiles><smiles>CCN1c2ccccc2N=C(C)C12SC(c1ccccc1)=NN2c1ccccc1</smiles>

FIgURE 2: Example of bioactive molecules derived from pyrazolo[3,4-d]pyrimidine and thiadiazole.

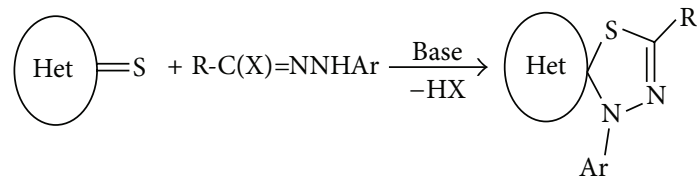

(A)

Figure 3: Synthesis of spiroheterocycles.

\section{Materials and Methods}

Generally the melting points were taken on an electrothermal capillary melting point apparatus. Infrared spectra $\left(\nu-\mathrm{cm}^{-1}\right)$

were recorded on a Perkin Elmer 577, using KBr disks. ${ }^{1} \mathrm{H}$ NMR and ${ }^{13} \mathrm{C}$ NMR spectra were recorded on Bruker Avance 300 NMR Spectrometer in DMSO- $d_{6}$. Spectra were internally referenced to TMS. Peaks are reported in ppm downfield of TMS. Mass spectra are recorded in a SYNAPT G2 HDMS (Waters) Spectrometer in electrospray ionization (ESI).

2.1. Thionation. $3.67 \mathrm{mmol}$ of pyrazolo[3,4-d]pyridine is refluxed in pyridine with $3.67 \mathrm{mmol}$ of phosphorus pentasulfide for 4 hours. Then the solvent is evaporated under reduced pressure, and the precipitate formed is washed with hot water to remove residual dimerized $\mathrm{P}_{2} \mathrm{~S}_{5}$ until there is colorless filtrate. 
1H-Pyrazolo[3,4-d]pyrimidine- $4(5 \mathrm{H})$-thione (2). Yield $=90 \%$; mp: $151^{\circ} \mathrm{C}$. IR: $\vartheta=1585 \mathrm{~cm}^{-1}{ }^{1} \mathrm{H}$ NMR (DMSO- $\left.d_{6}\right): \delta \mathrm{ppm}$ : $8.11(1 \mathrm{H}, \mathrm{s}, \mathrm{CH}) ; 8.22(1 \mathrm{H}, \mathrm{s}, \mathrm{CH}) ; 13.47(1 \mathrm{H}, \mathrm{s}, \mathrm{NH}) ; 13.92$ $(1 \mathrm{H}, \mathrm{s}, \mathrm{NH}) .{ }^{13} \mathrm{C}$ NMR (DMSO- $\left.d_{6}\right) \delta \mathrm{ppm}: 105.05 ; 134.05(\mathrm{Cq})$; $150.77(\mathrm{CH}) ; 151.20(\mathrm{CH}) ; 156.79(\mathrm{Cq} \mathrm{C}=\mathrm{S})$. HRMS (ESI) [M + $\mathrm{H}]: \mathrm{m} / \mathrm{z}=153.17$.

1,5-Diethyl-1H-pyrazolo[3,4-d]pyrimidine-4(5H)-thione (2a). Yield $=75 \%$; mp: $150^{\circ} \mathrm{C} .{ }^{1} \mathrm{H}$ NMR $\left(\right.$ DMSO $\left.-d_{6}\right) \delta \mathrm{ppm}: 1.3(3 \mathrm{H}$, $\left.\mathrm{t}, J=7.2 \mathrm{~Hz} . \mathrm{CH}_{3}\right) ; 1.36\left(3 \mathrm{H}, \mathrm{t}, J=7.2, \mathrm{CH}_{3}\right) ; 4.30(2 \mathrm{H}, \mathrm{q}, J=$ $\left.7.2 \mathrm{~Hz}, \mathrm{CH}_{2}\right) ; 4.51\left(2 \mathrm{H}, \mathrm{q}, J=7.2 \mathrm{~Hz}, \mathrm{CH}_{2}\right) ; 8.15(1 \mathrm{H}, \mathrm{s}, \mathrm{CH})$; $8.72(1 \mathrm{H}, \mathrm{s}, \mathrm{CH}) .{ }^{13} \mathrm{C}$ NMR (DMSO- $\left.d_{6}\right) \delta \mathrm{ppm}: 14.56\left(\mathrm{CH}_{3}\right)$; $15.15\left(\mathrm{CH}_{3}\right) ; 42.38\left(\mathrm{CH}_{2}\right) ; 46.34\left(\mathrm{CH}_{2}\right) ; 118.17 ; 137.09(\mathrm{Cq})$; $145.09(\mathrm{CH}) ; 149.99(\mathrm{CH}) ; 179.11(\mathrm{Cq}, \mathrm{C}=\mathrm{S})$. HRMS (ESI) [M + $\mathrm{H}]: \mathrm{m} / \mathrm{z}=209.07$.

1,5-Dibenzyl-1H-pyrazolo[3,4-d]pyrimidine-4(5H)-thione (2b). Yield $=70 \%$; mp: $160^{\circ} \mathrm{C} .{ }^{1} \mathrm{H}$ NMR (DMSO- $\left.d_{6}\right) \delta$ ppm: $3.25\left(2 \mathrm{H}, \mathrm{s}, \mathrm{CH}_{2}\right) ; 3.78\left(2 \mathrm{H}, \mathrm{s}, \mathrm{CH}_{2}\right) ; 6.85-7.12\left(\mathrm{q}, 10 \mathrm{H}_{\mathrm{Ar}}\right) ; 8.21$ $(1 \mathrm{H}, \mathrm{s}, \mathrm{CH}), 8.89(1 \mathrm{H}, \mathrm{s}, \mathrm{CH}) .{ }^{13} \mathrm{C}$ NMR $\left(\mathrm{DMSO}_{-} d_{6}\right) \delta \mathrm{ppm}$ : $51.83\left(\mathrm{CH}_{2}\right) ; 54.31\left(\mathrm{CH}_{2}\right) ; 118.24 ; 127.94(\mathrm{Cq}) ; 128.11-137.89$ $\left(\mathrm{CH}_{\mathrm{Ar}}\right) ; 145.54(\mathrm{CH}) ; 150.95(\mathrm{CH}) ; 179.82(\mathrm{Cq}, \mathrm{C}=\mathrm{S})$. HRMS (ESI) $[\mathrm{M}+\mathrm{H}]: \mathrm{m} / \mathrm{z}=33.10$.

2.2. 1,3-Dipolar Cycloaddition. To a solution of 1,5-diethyl$1 \mathrm{H}$-pyrazolo[3,4-d]pyrimidine- $4(5 \mathrm{H})$-thione $(10 \mathrm{mmol})$ and diphenylnitrilimine $(1.3 \times 10 \mathrm{mmol})$ in THF $(30 \mathrm{~mL})$ triethylamine $(2 \mathrm{~mL})$ was added. The mixture was refluxed for 24 hours. The precipitate was collected by filtration and was separated by silica gel chromatography (hexane/ethyl acetate: $8 / 2)$.

2,5-Diethyl-3', $5^{\prime}$-diphenyl-2,5-dihydro-3' H-spiro[pyrazolo[3, 4-d]pyrimidine-1, $2^{\prime}-[1,3,4]$ thiadiazole $]$ (4a). Yield $=60 \%$; $\mathrm{mp}$ : $165^{\circ} \mathrm{C} .{ }^{1} \mathrm{H}$ NMR (DMSO- $\left.d_{6}\right) \delta \mathrm{ppm} 1.12(3 \mathrm{H}, \mathrm{t}, J=7.2 \mathrm{~Hz}$, $\left.\mathrm{CH}_{3}\right) ; 1.28\left(3 \mathrm{H}, \mathrm{t}, J=7.2 \mathrm{~Hz}, \mathrm{CH}_{3}\right) ; 3.37(2 \mathrm{H}, \mathrm{q}, J=7.2 \mathrm{~Hz}$. $\left.\mathrm{CH}_{2}\right) ; 4.11\left(2 \mathrm{H}, \mathrm{q}, J=7.2 \mathrm{~Hz}, \mathrm{CH}_{2}\right) ; 6.83-7.67(\mathrm{q}, J=7.7 \mathrm{~Hz}$, $\left.10 \mathrm{H}_{\mathrm{Ar}}\right) ; 7.69(1 \mathrm{H}, \mathrm{s}, \mathrm{CH}) ; 7.69(1 \mathrm{H}, \mathrm{s}, \mathrm{CH}) .{ }^{13} \mathrm{C}$ NMR (DMSO$\left.d_{6}\right) \delta$ ppm: $15.61\left(\mathrm{CH}_{3}\right) ; 16.03\left(\mathrm{CH}_{3}\right) ; 41.88\left(\mathrm{CH}_{2}\right) ; 42.28$ $\left(\mathrm{CH}_{2}\right) ; 99.70 ; 100.79 ; 117.03 ; 126.38(\mathrm{Cq}) ; 129.26-142.20$ $\left(\mathrm{CH}_{\mathrm{Ar}}\right) ; 143.87(\mathrm{CH}) ; 148.01(\mathrm{CH})$. HRMS (ESI) $[\mathrm{M}+\mathrm{H}]$ : $\mathrm{m} / \mathrm{z}=403.16$.

2,5-Dibenzyl-3', 5'-diphenyl-2,5-dihydro-3' H-spiro[pyrazolo $[3,4-d]$ pyrimidine-1, $2^{\prime}-[1,3,4]$ thiadiazole $](4 \mathbf{b})$. Yield $=60 \%$; mp: $185^{\circ} \mathrm{C} .{ }^{1} \mathrm{H}$ NMR (DMSO- $\left.d_{6}\right) \delta$ ppm: $3.65\left(2 \mathrm{H}, \mathrm{s}, \mathrm{CH}_{2}\right.$ ); $4.28\left(2 \mathrm{H}, \mathrm{s}, \mathrm{CH}_{2}\right) ; 7.25-7.32\left(\mathrm{q}, J=7.2 \mathrm{~Hz}, 20 \mathrm{H}_{\mathrm{Ar}}\right) ; 8.81(1 \mathrm{H}$, s, CH); $8.99(1 \mathrm{H}, \mathrm{s}, \mathrm{CH}) .{ }^{13} \mathrm{C}$ NMR (DMSO- $\left.d_{6}\right) \delta \mathrm{ppm}: 50.83$ $\left(\mathrm{CH}_{2}\right)$; $53.21\left(\mathrm{CH}_{2}\right) ; 77.2 ; 118.24 ; 121.02 ; 125.13 ; 127.94 ; 128.04$; $128.15 ; 128.46$; $128.79(\mathrm{Cq}) ; 129.12-137.9\left(\mathrm{CH}_{\mathrm{Ar}}\right) ; 145.54(\mathrm{CH})$; $150.95(\mathrm{CH}) . \mathrm{HRM}(\mathrm{ESI})[\mathrm{M}+\mathrm{H}]: \mathrm{m} / \mathrm{z}=527.39$.

\section{Results and Discussion}

We first prepared 1,5-diethyl-1H-pyrazolo[3,4-d]pyrimidine$4(5 \mathrm{H})$-thiones $\mathbf{2 a}$-b from $\mathbf{l a}-\mathbf{b}$ by refluxing phosphorus pentasulfide in pyridine. The identification of the product was determined by ${ }^{1} \mathrm{H}$ NMR, ${ }^{13} \mathrm{C}$ NMR, IR, and mass spectra.

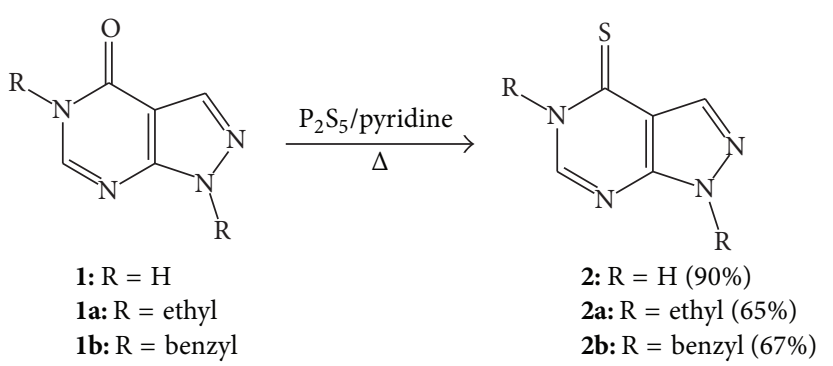

SCHEme 1: Thionation of 1,5-dialkyl-1H-pyrazolo[3,4-d]pyrimidin$4(5 \mathrm{H})$-one la-b.

IR-spectra of compounds 2a-d did not contain C=Ogroup signals, the signal of $\mathrm{C}=\mathrm{S}$ group $\left(1500 \mathrm{~cm}^{-1}\right)$ was present. The spectra of ${ }^{13} \mathrm{C}$ NMR corroborated the results of IR. In addition, its mass spectrum shows a molecular ion peak at $\mathrm{m} / \mathrm{z} 152(\mathrm{M}+)$ corresponding to the molecular formula $\mathrm{C}_{5} \mathrm{H}_{4} \mathrm{~N}_{4} \mathrm{~S}$ compound 2, molecular ion at $\mathrm{m} / \mathrm{z} 208.07$ $(\mathrm{M}+)$ corresponding to the molecular formula $\mathrm{C}_{9} \mathrm{H}_{12} \mathrm{~N}_{4} \mathrm{~S}$ compound $\mathbf{2 a}$ and molecular ion at $\mathrm{m} / \mathrm{z} 332.10(\mathrm{M}+)$ corresponding to the molecular formula $\mathrm{C}_{19} \mathrm{H}_{16} \mathrm{~N}_{4} \mathrm{~S}$ compound $\mathbf{2 b}$ (Scheme 1, Figure 4) [23].

We investigated the reaction of 1,3-dipolar cycloaddition of diphenyl hydrazonoyl chloride 3 with equimolecular amount of 1,5-diethyl-1H-pyrazolo[3,4-d]pyrimidin-4(5H)thione 2a in dry tetrahydrofuran in presence of triethylamine (Scheme 2); one cycloadduct was obtained as a result of 1,3-dipolar cycloaddition of diphenyl nitrile imine ylide generated in situ from diphenyl hydrazonoyl chloride and triethylamine, on the dipolarophilic group $\mathrm{C}=\mathrm{S}$.

The structure of these compounds was confirmed on the basis of their spectroscopic characteristics. The ${ }^{1} \mathrm{H}$ NMR spectra of $4 \mathbf{a}$ (in DMSO- $d_{6}$ ) showed an aromatic multiplet in the region of 6.83 to $7.67 \mathrm{ppm}$ corresponding to the aromatic protons. Two downfield singlets were observed in the region of 7691-7968 ppm representing the protons for $\mathrm{CH}$ in pyrimidine ring and $\mathrm{CH}$ in pyrazole ring because of the high incidence of the aromatic ring system deshielding protons $\mathrm{CH}$ pyrimidine $\mathrm{CH}$ pyrazole. $1 \mathrm{H}$ NMR spectra of 4a also showed the $\mathrm{CH}_{2}$ and $\mathrm{CH}_{3}$ signals as triplets and multiplets and between 1.12 and $1.27 \mathrm{ppm}$ and between 3.37 and $4.11 \mathrm{ppm}$, respectively. ${ }^{13} \mathrm{C}$ NMR spectra of $4 \mathbf{a}$ exhibit in signal spirocarbon to $99.70 \mathrm{ppm}$, aromatic carbons 100.79 to $129.38 \mathrm{ppm}$, and the imine carbon to 142.2 and $139.93 \mathrm{ppm}$ $(\mathrm{HC}=\mathrm{N})$. The mass spectrum shows a peak at $\mathrm{m} / \mathrm{z} 403.16$ corresponding to $[\mathrm{M}+\mathrm{H}]$.

In order to examine the $\mathrm{N}$-substitution effect of alkyl group on the 1,3-dipolar cycloaddition, 1,5-dibenzyl-1Hpyrazolo[3,4-d]pyrimidin- $4(5 \mathrm{H})$-thione $\mathbf{2 a}$ was chosen to be employed to react with DPNI. So in this case it was found that $\mathrm{C}=\mathrm{S}$ group underwent the 1,3-dipolar cycloaddition reaction and formed of novel spiro[thiadiazoline-(pyrazolo[3,4d]pyrimidine)] (Scheme 3).

The structure of compound $\mathbf{4 b}$ was established by IR, ${ }^{1} \mathrm{H}$ NMR, ${ }^{13} \mathrm{C}$ NMR, and mass spectrum. Its IR spectrum showed a characteristic absorption band at $1647 \mathrm{~cm}^{-1}$ for the $>\mathrm{C}=\mathrm{N}$ - indicating the spirocarbon formation. Its ${ }^{1} \mathrm{H}$ NMR 


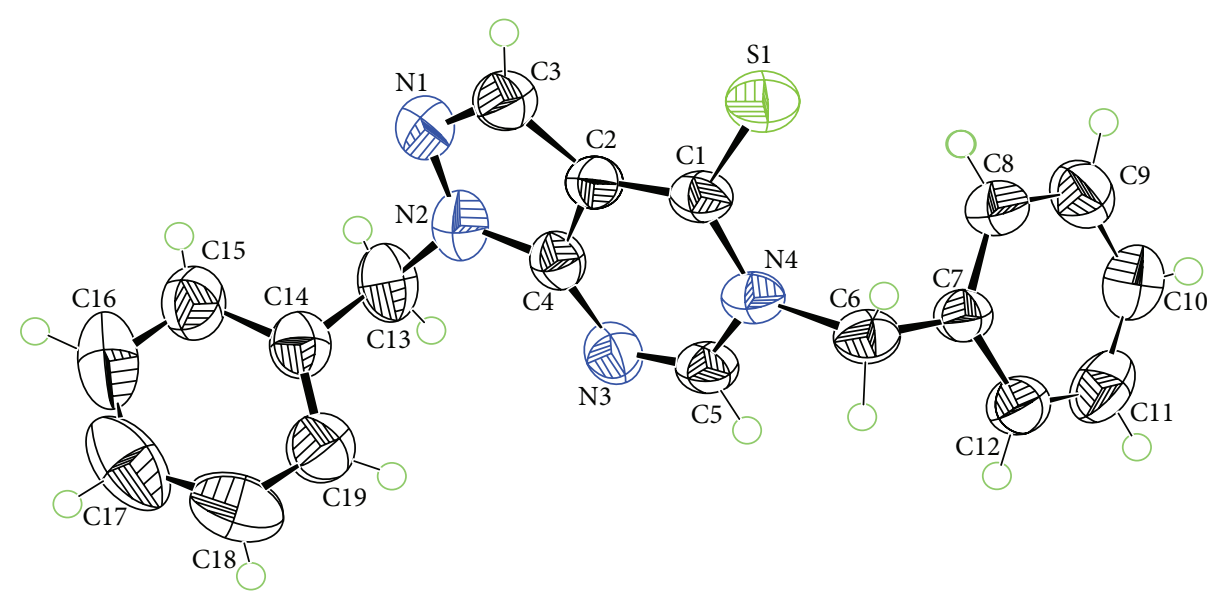

FIGURE 4: ORTEP presentation of compound $\mathbf{2 b}$.<smiles>CCn1cnc2c(cnn2[18F])c1=S</smiles>

2a<smiles>Cl/C(=N\Nc1ccccc1)c1ccccc1</smiles><smiles>CCN1C=Nc2c(cnn2CC)C12SC(c1ccccc1)=NN2c1ccccc1</smiles>

$4 a$

Scheme 2: 1,3-Dipolar cycloaddition of 1,5-diethyl-1H-pyrazolo[3,4-d]pyrimidine-4(5H)-thione 2a and DPNI 3.<smiles>S=c1c2cnn(Cc3ccccc3)c2ncn1Cc1ccccc1</smiles>

$2 b$<smiles>Cl/C(=N\Nc1ccccc1)c1ccccc1</smiles>

3<smiles>C1=Nc2c(cnn2Cc2ccccc2)C2(S1)N(Cc1ccccc1)C=NN2c1ccccc1</smiles>

$4 b$

Scheme 3: 1,3-Dipolar cycloaddition of 1,5-dibenzyl-1H-pyrazolo[3,4-d]pyrimidine-4(5H)-thione $2 \mathbf{b}$ and DPNI.

spectrum exhibited peaks at 7.25-7.32 ppm $(20 \mathrm{H})$ indicating the presence of aromatic protons. The two singlets at $3.65 \mathrm{ppm}$ and $4.28 \mathrm{ppm}$ relating to two protons of the two $\mathrm{CH}_{2}$ groups were also observed. ${ }^{13} \mathrm{C}$ NMR spectra of $\mathbf{4} \mathbf{b}$ exhibited, in particular, a spiro carbon signal at $77.2 \mathrm{ppm}$. The mass spectrum shows a peak at $\mathrm{m} / \mathrm{z} 527.39$ corresponding to [M $+\mathrm{H}]$.

3.1. In Vitro Antibacterial Activity. We studied spiropyrazolo[3,4-d]pyrimidines newly synthesized for their antibacterial activity against Escherichia coli (ATTC-25922), Staphylococcus aureus (ATCC-25923), Pseudomonas aeruginosa (ATCC 27853), and Enterococcus faecalis (ATCC-29212) strains of bacteria by the diffusion method disk [32]. The
MIC values of the compound against bacteria are presented in Table 1.

We synthesized new spirocompounds with a high yield by cycloaddition reaction. They have showed moderate antibacterial activity against selected bacteria. All these compounds showed at an average concentration low antibacterial activity against the bacteria, except that compounds la and $\mathbf{4 a}$ showed higher activity, even at higher concentrations. Compound 4b showed higher activity against $S$. aureus and E. faecalis compared to bacteria E. coli and P. aeruginosa.

\section{Conclusion}

In conclusion, a new class of heterocyclic spiro[thiadiazoline pyrazolopyrimidine] compounds was synthesized and their 
TABLE 1: Antibacterial activity of the compounds: MIC in $\mu \mathrm{g} / \mathrm{mL}$.

\begin{tabular}{lcccc}
\hline \multirow{2}{*}{ Product } & \multicolumn{4}{c}{ MIC in $\mu \mathrm{g} / \mu \mathrm{L}$} \\
& S. aureus & E. faecalis & E. coli & P. aeruginosa \\
\hline $\mathbf{1}$ & 250 & 125 & 250 & 250 \\
$\mathbf{1 a}$ & 250 & 250 & 250 & - \\
$\mathbf{1 b}$ & 125 & 62.5 & 62.5 & 250 \\
$\mathbf{2}$ & 250 & 125 & 125 & 250 \\
$\mathbf{2 a}$ & 250 & 125 & 250 & 250 \\
$\mathbf{2 b}$ & 250 & 250 & 250 & 250 \\
$\mathbf{4 a}$ & 125 & 62.5 & 125 & 250 \\
$\mathbf{4 b}$ & 31.25 & 31.25 & 125 & 125 \\
Chlor & 1.875 & 3.75 & 15 & 7.5 \\
Amp & 2.5 & 1.25 & 5 & 5 \\
\hline
\end{tabular}

MIC: minimum inhibitory concentration.

structure was determined and also tested for their antibacterial activity in vitro. This study is expected to take the tests of anti-inflammatory drugs, antifungal, and anticancer activity because the literature gives some very interesting results on these topics.

\section{Conflict of Interests}

The authors declare that there is no conflict of interests regarding the publication of this paper.

\section{Acknowledgment}

The authors thank Pharmaceutical Laboratories PHARMA 5 for supporting this study.

\section{References}

[1] P. Dinér, J. P. Alao, J. Söderlund, P. Sunnerhagen, and M. Grøtli, "Preparation of 3-substituted-1-isopropyl-1 H-pyrazolo[3,4d]pyrimidin-4- amines as RET kinase inhibitors," Journal of Medicinal Chemistry, vol. 55, no. 10, pp. 4872-4876, 2012.

[2] L. L. Yang, G. B. Li, H. X. Yan et al., "Discovery of N6phenyl-1H-pyrazolo[3,4-d]pyrimidine-3,6-diamine derivatives as novel CK1 inhibitors using common-feature pharmacophore model based virtual screening and hit-to-lead optimization," European Journal of Medicinal Chemistry, vol. 56, pp. 30-38, 2012.

[3] J.-H. Chern, K.-S. Shia, T.-A. Hsu et al., "Design, synthesis, and structure-activity relationships of pyrazolo[3,4-d]pyrimidines: a novel class of potent enterovirus inhibitors," Bioorganic and Medicinal Chemistry Letters, vol. 14, no. 10, pp. 2519-2525, 2004.

[4] T. A. Bektemirov, E. V. Chekunova, I. A. Korbukh, N. Bulychev Yu, N. G. Yakunina, and M. N. Preobrazhenskaya, "Antiviral activity of substituted 6-methylmercaptopyrazolo(3,4d)pyrimidines and their ribosides," Acta Virologica, vol. 25 , no. 5 , pp. 326-329, 1981.

[5] S. Taliani, C. La Motta, L. Mugnaini et al., "Novel $N^{2}$ Substituted pyrazolo $[3,4-d]$ pyrimidine adenosine $\mathrm{A}_{3}$ receptor antagonists: inhibition of $\mathrm{A}_{3}$-Mediated human glioblastoma cell proliferation," Journal of Medicinal Chemistry, vol. 53, no. 10, pp. 3954-3963, 2010.
[6] D. Briel, R. Aurich, U. Egerland, and K. Unverferth, "Synthese substituierter 6-Phenylpyrazolo[3,4-d]pyrimidine mit potenziell Adenosin- $\mathrm{A}_{2 \mathrm{~A}}$-antagonistischer Wirkung," Die Pharmazie, vol. 60, no. 10, pp. 732-735, 2005.

[7] S.-A. Poulsen and R. J. Quinn, "Synthesis and structure-activity relationship of pyrazolo[3,4- d]pyrimidines: potent and selective adenosine $A_{1}$ receptor antagonists," Journal of Medicinal Chemistry, vol. 39, no. 21, pp. 4156-4161, 1996.

[8] C. M. Niswender, E. P. Lebois, Q. Luo et al., "Synthesis and antitubercular evaluation of some novel pyrazolo[3,4-d]pyrimidine derivatives," Medicinal Chemistry Research, vol. 21, pp. 18871891, 2012.

[9] B. S. Holla, M. Mahalinga, M. S. Karthikeyan, P. M. Akberali, and N. S. Shetty, "Synthesis of some novel pyrazolo[3,4d]pyrimidine derivatives as potential antimicrobial agents," Bioorganic and Medicinal Chemistry, vol. 14, no. 6, pp. 20402047, 2006.

[10] D. Bhambi, V. K. Salvi, J. L. Jat, S. Ojha, and G. L. Talesara, "Synthesis and antimicrobial activity of some new indole containing isoxazolines and phthalimidoxy derivatives of thiazolidinone and thiohydantoin," Journal of Sulfur Chemistry, vol. 28, no. 2, pp. 155-163, 2007.

[11] R. A. M. Fatty, A. M. Gaafar, and A. M. S. Youssef, "A simple and efficient synthesis of new substituted benzothienopyridazine spiro- derivatives of pyrazolone, pyrimidinone and diazepinone," Journal of Chemical and Pharmaceutical Research, vol. 3, pp. 222-228, 2011.

[12] N. N. Gajera and M. C. Patel, "Synthesis, characterization and biological screening of new spirochromanones," Journal of Chemical and Pharmaceutical Research, vol. 4, no. 7, pp. 33773382, 2012.

[13] B. S. Rane, S. V. Deshmukh, M. G. Ghagare, R. V. Rote, and M. N. Jachak, "Synthesis of spiro-pyrimido [4,5-b]quinoline and study of their antimicrobial activities," Journal of Chemical and Pharmaceutical Research, vol. 4, no. 7, pp. 3562-3567, 2012.

[14] J. R. Yerrabelly, V. Chakravarthula, H. Yerrabelly et al., "Unusual tandem ring closing metathesis-Claisen rearrangement enroute to spiro annulation of O-allyl biscoumarins," Tetrahedron Letters, vol. 56, no. 17, pp. 2180-2182, 2015.

[15] K. De, A. Bhaumik, B. Banerjee, and C. Mukhopadhyay, "An expeditious and efficient synthesis of spiro-pyrazolo[3,4b]pyridines catalysed by recyclable mesoporous aluminosilicate nanoparticles in aqueous-ethanol," Tetrahedron Letters, vol. 56, no. 13, pp. 1614-1618, 2015.

[16] S. Abouricha, E. M. Rakib, N. Benchat, M. Alaoui, H. Allouchi, and B. El Bali, "Facile synthesis of new spirothiadiazolopyridazines by 1,3-dipolar cycloaddition," Synthetic Communications, vol. 35, no. 16, pp. 2213-2221, 2005.

[17] E. V. Budarina, N. N. Labeish, V. K. Bel'Skii, and V. A. Galishev, "Hetrocyclic thiones and their analogs in reactions of 1,3-dipolar addition: v. Reactions of 2,3,3-triphenyl1-thioxophthalimidine with nitrile imines," Russian Journal of Organic Chemistry, vol. 41, no. 5, pp. 758-761, 2005.

[18] E. M. Essassi, C. Ahoya, R. Bouhfid et al., "Synthesis and antibacterial activity of new spiro[thiadiazoline-quinoxaline] derivatives," Arkivoc, vol. 2011, no. 2, pp. 217-226, 2011.

[19] K. Al Mamari, H. Ennajih, H. Zouihri, R. Bouhfid, S. W. $\mathrm{Ng}$, and E. M. Essassi, "Synthesis of novel dispiro-oxindoles via 1,3-dipolar cycloaddition reactions of azomethine ylides," Tetrahedron Letters, vol. 53, no. 18, pp. 2328-2331, 2012.

[20] Y.-X. Zhang, L. Ding, X.-Y. Liu et al., "Spiro-fused Nphenylcarbazole-based host materials for blue phosphorescent 
organic light-emitting diodes," Organic Electronics, vol. 20, pp. 112-118, 2015.

[21] P. Das, A. O. Omollo, L. J. Sitole et al., "Synthesis and investigation of novel spiro-isoxazolines as anti-cancer agents," Tetrahedron Letters, vol. 56, no. 14, pp. 1794-1797, 2015.

[22] J. Naga Siva Rao and R. Raghunathan, "A facile synthesis of glyco 3-nitrochromane hybrid pyrrolidinyl spiro heterocycles via [3+2] cycloaddition of azomethine ylides," Tetrahedron Letters, vol. 56, no. 17, pp. 2276-2279, 2015.

[23] M. El Fal, Y. Ramli, E. M. Essassi, M. Saadi, and L. El Ammari, "The crystal structure of 1,5-dibenzyl-1H-pyrazolo[3,4-d]pyrimidine-4(5H)-thione," Acta Crystallographica E, vol. 71, pp. o95-o96, 2015.

[24] M. El Fal, Y. Ramli, E. M. Essassi, M. Saadi, and L. El Ammari, "Crystal structure of 4-allylsulfanyl- $1 H$-pyrazolo[3,4d]pyrimidine," Acta Crystallographica E, vol. 70, p. o1038, 2014.

[25] M. El Fal, Y. Ramli, E. M. Essassi, M. Saadi, and L. El Ammari, "Crystal structure of 1-ethylpyrazolo[3,4- $d]$ pyrimidine-4 $(5 H)$ thione," Acta Crystallographica Section E: Structure Reports Online, vol. 70, no. 9, pp. o1005-o1006, 2014.

[26] A. Alsubari, Y. Ramli, E. M. Essassi, and H. Zouihri, "5(Pyridin-4-ylmeth-yl)-1Hpyrazolo-[3,4-d]pyrimidin-4(5H)one," Acta Crystallographica Section E: Structure Reports Online, vol. 67, part 8, Article ID o1926, 2011.

[27] M. El Fal, Y. Ramli, E. M. Essassi, M. Saadi, and L. El Ammari, "4-benzylsulfanyl-1H-pyrazolo[3,4-d]pyrimidine," Acta Crystallographica Section E, vol. 69, no. 11, p. o1650, 2013.

[28] M. El Fal, Y. Ramli, E. M. Essassi, M. Saadi, and L. El Ammari, "Crystal structure of 1-methyl-4-methylsulfanyl-1Hpyrazolo[3,4-d]pyrimidine," Acta Crystallographica, vol. E70, Article ID o1281, 2014.

[29] I. El Ouali, B. Hammouti, A. Aouniti et al., "Thermodynamic characterisation of steel corrosion in $\mathrm{HCl}$ in the presence of 2-phenylthieno (3, 2-b) quinoxaline," Journal of Materials and Environmental Science, vol. 1, no. 1, pp. 1-8, 2010.

[30] M. Z. A. Badr, G. M. El-Naggar, H. A. H. El-Sherief, A. E. S. Abdel-Rahman, and M. F. Aly, "Reaction of quinoxaline derivatives with nucleophilic reagents," Bulletin of the Chemical Society of Japan, vol. 56, no. 1, pp. 326-330, 1983.

[31] O. S. Moustafa, "Synthesis and some reactions of Quinoxalinecarboazides," Journal of the Chinese Chemical Society, vol. 47, pp. 351-357, 2000.

[32] J. Sirot, Bactériologie Médicale, Flammarion, Paris, France, 2nd edition, 1990. 

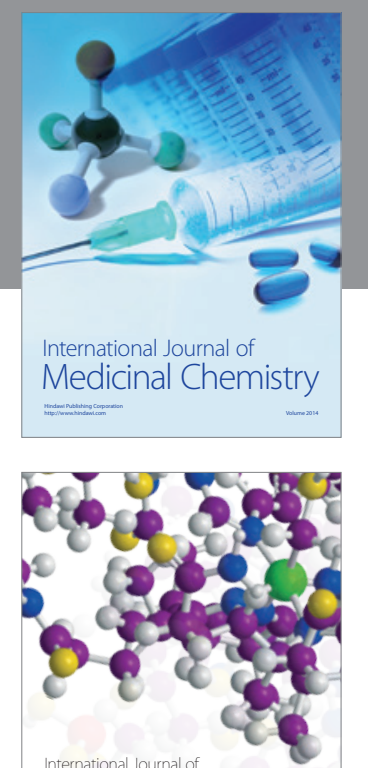

\section{Carbohydrate} Chemistry

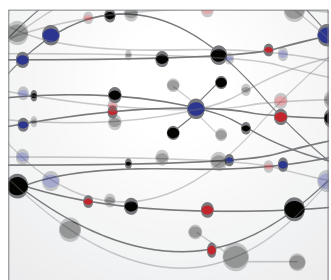

The Scientific World Journal
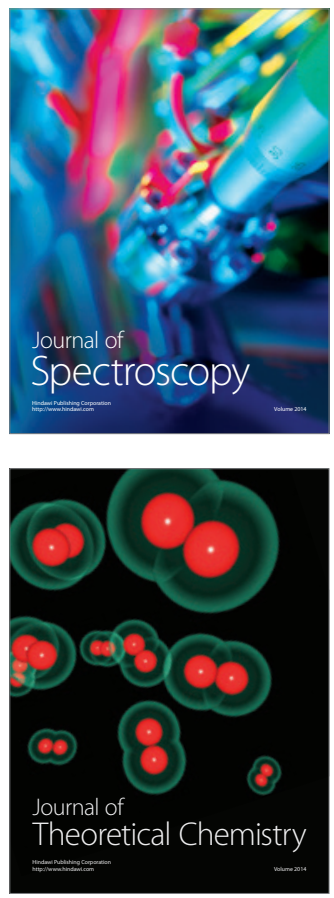
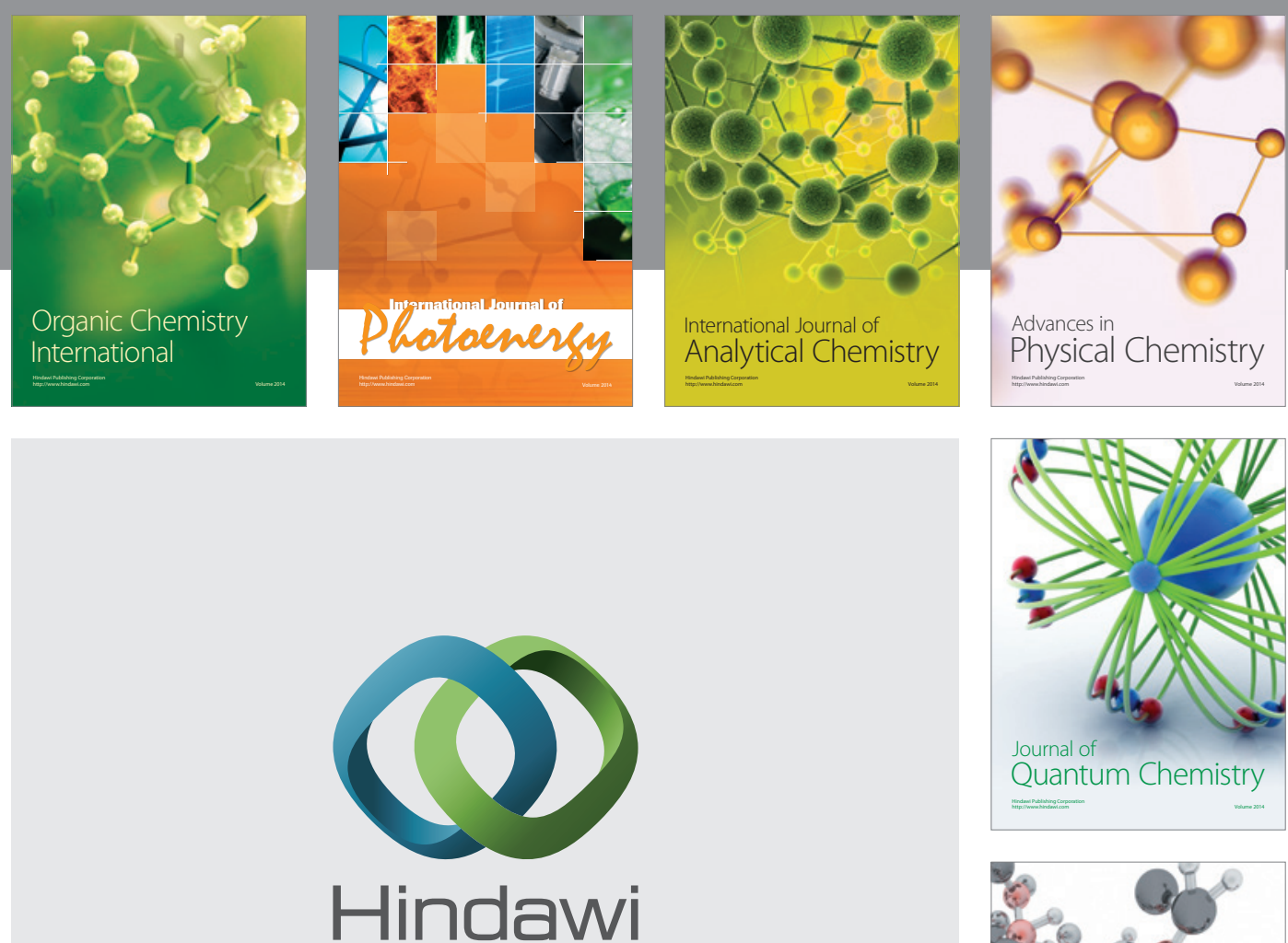

Submit your manuscripts at

http://www.hindawi.com

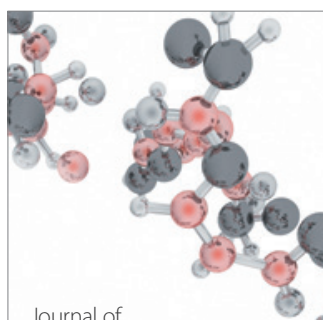

Analytical Methods

in Chemistry

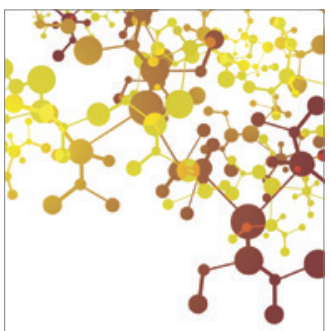

Journal of

Applied Chemistry

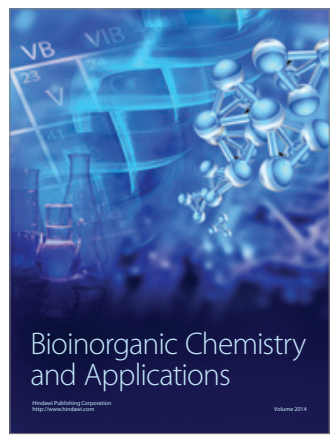

Inorganic Chemistry
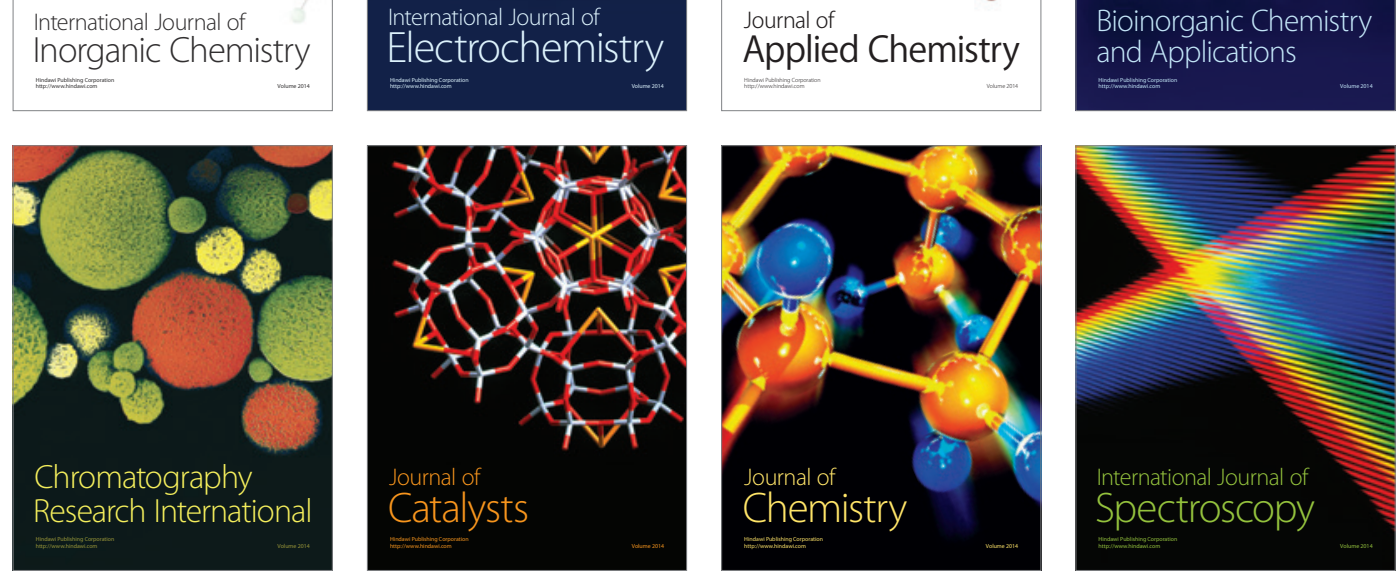